\title{
Lactoferrin Induces Concentration-Dependent Functional Modulation of Intestinal Proliferation and Differentiation
}

\author{
VITTORIA BUCCIGROSSI, GIULIO DE MARCO, EUGENIA BRUZZESE, LUIGI OMBRATO, ILEANA BRACALE, \\ GAETANO POLITO, AND ALFREDO GUARINO
}

Department of Pediatrics, University of Naples “Federico II," Via S. Pansini 5, 80131, Naples, Italy

\begin{abstract}
Human milk stimulates intestinal development through the effects of various moieties. Lactoferrin (LF) is a glycoprotein of human milk whose concentration is highest in colostrum decreasing in mature milk. LF promotes enterocyte growth in intestinal cell lines. We tested the hypothesis that LF induces a distinct effect on enterocyte proliferation and differentiation, depending on its concentration. We examined the dose-related effects by humannative LF (N-LF) in Caco-2 (human colon adenocarcinoma) cells. At high concentrations, N-LF stimulated cell proliferation in immature Caco- 2 cells, as judged by ${ }^{3} \mathrm{H}$-thymidine incorporation. In contrast, sucrase and lactase activities were increased at low but not high LF concentrations and their mRNA were also increased, indicating a transcriptional effect. Because iron binds specific LF sites, we compared the potency of N-LF and iron-saturated LF (I-LF) and found the native form more potent. Finally, we tested the effects by bovine LF (bLF) in the same system and found the latter more potent than the human isoform in inducing cell growth and lactase expression. These results suggest that LF directly induces enterocyte growth and proliferation, depending on its concentration, thereby regulating the earlyx postnatal intestinal development. bLF could be added to infant formula as a growth factor in selected intestinal diseases. (Pediatr Res 61: 410-414, 2007)
\end{abstract}

$I^{\prime}$ ntestinal epithelial development changes immediately after birth, with an age-dependent enterocyte proliferation and differentiation pattern (1). Intestinal cell growth peaks at birth $(2,3)$ upon the stimulation exerted by growth factors in amniotic fluid and in human milk $(4,5)$, but also as a consequence of dietary changes (6). Intestinal epithelial growth and development is faster in breast-fed than in formula-fed infants. Brush border enzymes such as lactase and sucrase also show an increased activity and correlate with epithelial differentiation (7-10). Human colostrum possesses a potent growthpromoting activity, which decreases within a few days, and milk formula has no such effect (3). Colostrum and human mature milk contain many growth factors, including EGF, IGF-I, and HGF, the concentrations of which change during lactation $(4,5,11)$. LF, an iron-binding $80-\mathrm{kDa}$ glycoprotein (12), is found in amniotic fluid and mammalian milk in iron-saturated and iron-unsaturated forms $(13,14)$. Its concentration in human milk is related to infant age: it peaks in

Received August 10, 2006; accepted November 22, 2006.

Correspondence: Alfredo Guarino, M.D., Department of Pediatrics, University Federico II of Naples, Via S. Pansini 5, 80131 Naples, Italy; e-mail: alfguari@unina.it

Supported by a grant from the Ministry of Health 4th AIDS Project, Program 50D.28.

DOI: $10.1203 /$ pdr.0b013e3180332c8d colostrum and rapidly decreases in mature milk (15). It has been reported that LF resists proteolysis through the infant's digestive tract (16) and binds to a specific receptor located on the enterocyte brush-border (17). Human LF induced intestinal proliferation and differentiation in the Caco-2 intestinal cell line (18). Although digestive enzyme activities increase along the crypt villus axis (19), proliferation and differentiation are not simultaneous processes and need to be finely tuned, particularly in newborn infants, in whom the enterocytes have not yet acquired the features of mature, ionabsorptive cells. The aim of this study was to test the hypothesis that LF induces concentration-dependent functional modulation of intestinal epithelial proliferation and differentiation, thereby contributing to the fine tuning of early development of intestinal epithelium.

In human milk, native LF is a combination of $10 \%$ ironsaturated LF and $90 \%$ iron-unsaturated isoforms (15). This ratio is stable. Because evidence has been produced that different LF isoforms exert different biologic effects $(18,20)$, we tested the effects of N-LF (10\% iron-saturated isoform or native LF) in comparison with I-LF (100\% iron-saturated isoform). We investigated the effects of a wide range of LF concentrations on proliferation and on differentiation markers in rapidly growing intestinal Caco- 2 cells. Caco- 2 is an established human-derived intestinal cell line that differentiates into mature human enterocytes generating monolayers of polarized cells (21-23). To monitor cell differentiation, we determined sucrase and lactase activities. The latter increases with age in the first weeks of life and it was increased in milk-fed more than in formula-fed infants $(6,7)$.

Finally, because bLF shows a strong sequence amino acid homology with human LF (NCBI protein-protein BLAST) (24), we compared the biologic effects of bovine and human LF. This was done to see whether bLF was a potential functional nutrient to be added to infant formula to achieve clinical effects.

\section{MATERIALS AND METHODS}

Cell line. Caco-2 cells were obtained from the American Type Culture Collection (Rockville, MD). Cells were grown in Dulbecco's modified Eagle's medium (DMEM, Invitrogen, Carlsbad, CA) with a high glucose concentration ( $4.5 \mathrm{~g} / \mathrm{L}$ ) supplemented with $10 \%$ fetal bovine serum (FBS), $1 \%$

Abbreviations: bLF, bovine native lactoferrin; Caco-2, human colon adenocarcinoma; I-LF, human iron-saturated lactoferrin; LF, lactoferrin; N-LF, human native lactoferrin 
nonessential amino acids, penicillin $(50 \mathrm{mU} / \mathrm{mL})$, and streptomycin $(50$ $\mathrm{mg} / \mathrm{mL}$ ) and kept in $5 \% \mathrm{CO}_{2}-95 \%$ air. Cells were used between the 20th and 40th passage and the medium was changed daily.

Cell growth. Caco-2 cells were seeded onto 96-well microtiter plates $\left(10^{4}\right.$ cells/well) and cultured for $3 \mathrm{~d}$ in DMEM with $10 \%$ FBS. After $24 \mathrm{~h}$ of serum starvation, cells were exposed to increasing doses of LF for $48 \mathrm{~h}$ in DMEM FBS-free; then ${ }^{3} \mathrm{H}$-thymidine $(0.5 \mu \mathrm{Ci} /$ well, ICN Biomedicals, Irvine, CA) was added $18 \mathrm{~h}$ before harvesting the cells with a semiautomatic cell harvester (Skatron Instruments, Lier, Norway). The filters were dried and beta radioactivity was counted with a Packard scintillation spectrometer (Packard Instrument Co., Meriden, CT). The same experiment was repeated after 10 and $17 \mathrm{~d}$ from plating. For cell counts, cells were seeded onto 24-well plates $\left(7 \times 10^{4}\right.$ cells/well), cultured, and stimulated under the same experimental conditions and counted in a Neubauer chamber.

Lactase and sucrase activity assays. Cells were collected after $24 \mathrm{~h}$ of LF stimulation and lactase and sucrase enzymatic activities were measured by modified Dahlqvist method (25). Briefly, cells were rinsed in cold PBS and scraped into cold maleate buffer $0.1 \mathrm{M} \mathrm{pH}$ 6.0. Samples were sonicated three times for $15 \mathrm{~s}$ each, using a Labsonic 2000 (Sartorius AG, Goettingen, Germany) and total cell lysates were incubated at $37^{\circ} \mathrm{C}$ with $50 \mathrm{mM}$ lactose for $60 \mathrm{~min}$ or sucrose for $30 \mathrm{~min}$. The glucose generated by enzymatic activity was measured using a glucose oxidase assay.

Comparative effects of human and bovine LF. Experiments were run in parallel to test the effects of bovine LF on Caco-2 cell growth and differentiation. Bovine LF was used in concentrations equimolar to human LF.

RNA extraction and reverse transcription. Preconfluent Caco- 2 cells were collected after $24 \mathrm{~h}$ of bLF stimulation and total RNA has been extracted from Caco-2 cells by TRIzol reagent protocol (Invitrogen). The amount of extracted RNA was quantified by measuring the absorbance at $260 \mathrm{~nm}$. Reverse transcription of RNA was performed using a High-Capacity cDNA Archive Kit (Applied Biosystems, Foster City, CA).

Quantitative real-time $R$ T-PCR. Real-time RT-PCR was performed according to the recommendations supplied by Applied Biosystems (available at: http://europe.appliedbiosystems.com/). Primers for sucrase (Hs00356112_m1) and lactase (Hs00158722_m1) were purchased from Applied Biosystems. A $25-\mu \mathrm{L}$ PCR reaction volume was prepared using about $40 \mathrm{ng}$ of cDNA as template. Reactions were run in 96-well optical reaction plates using an Applied Biosystems 7300 Real-Time PCR System. Thermal cycles were set at $95^{\circ} \mathrm{C}(10 \mathrm{~min})$ and then 35 cycles at $95^{\circ} \mathrm{C}(15 \mathrm{~s})$ and $60^{\circ} \mathrm{C}$ (1 min) with auto ramp time. For data analysis, the threshold line was set automatically and it was in the linear range of the amplification curves for all mRNA in all experimental runs. All reactions were performed in triplicate. The abundance of target mRNA was calculated relative to a reference mRNA $(\mathrm{GAPDH})$. Relative expression ratios were calculated as $\mathrm{R}=2^{(\mathrm{Ct}(\beta 2}$ micro globulin) - Ct(test)), where $\mathrm{Ct}$ is the cycle number at the threshold and the test stands for the tested mRNA. The confidence interval was fixed at $95 \%$.

Reagents. N-LF with $10 \%$ iron-saturation, iron-saturated isoform from human milk, and all reagents were purchased from Sigma Chemical Co. (St. Louis, MO). N-LF from bovine milk was kindly provided by Prof. P. Valenti (Department of Experimental Medicine, II University of Naples, Naples, Italy).

Statistical analysis. Each experiment was run in triplicate and was repeated at least three times. Results are expressed as mean \pm SD. Significance was evaluated by $t$ test. Results were considered significant at $p<0.05$.

\section{RESULTS}

Effects of LF on cell growth. ${ }^{3} \mathrm{H}$-thymidine incorporation was increased in Caco- 2 cells exposed to N-LF (Fig. 1A) after $3 \mathrm{~d}$ postplating. N-LF stimulated cell growth at a concentration as low as $1 \mu \mathrm{g} / \mathrm{mL}$, as judged by ${ }^{3} \mathrm{H}$-thymidine uptake. The effect increased in a dose-dependent fashion peaking at $100 \mu \mathrm{g} / \mathrm{mL}$. Higher concentrations did not induce further proliferation, indicating a saturation pattern of the effect. The experiments were repeated using cell count to monitor cell proliferation. A near-perfect correlation was observed between the two cell proliferation markers (Fig. 1B). We repeated the same experiment at $\mathrm{d} 10$ and 17 postplating using LF concentration of 1 and $100 \mu \mathrm{g} / \mathrm{mL}$ (Fig. 2, $A$ and $B$, respectively). The proliferative effect induced by N-LF was maximal at $100 \mu \mathrm{g} / \mathrm{mL}$ in preconfluent condition, but it was progressively lost in older cells.

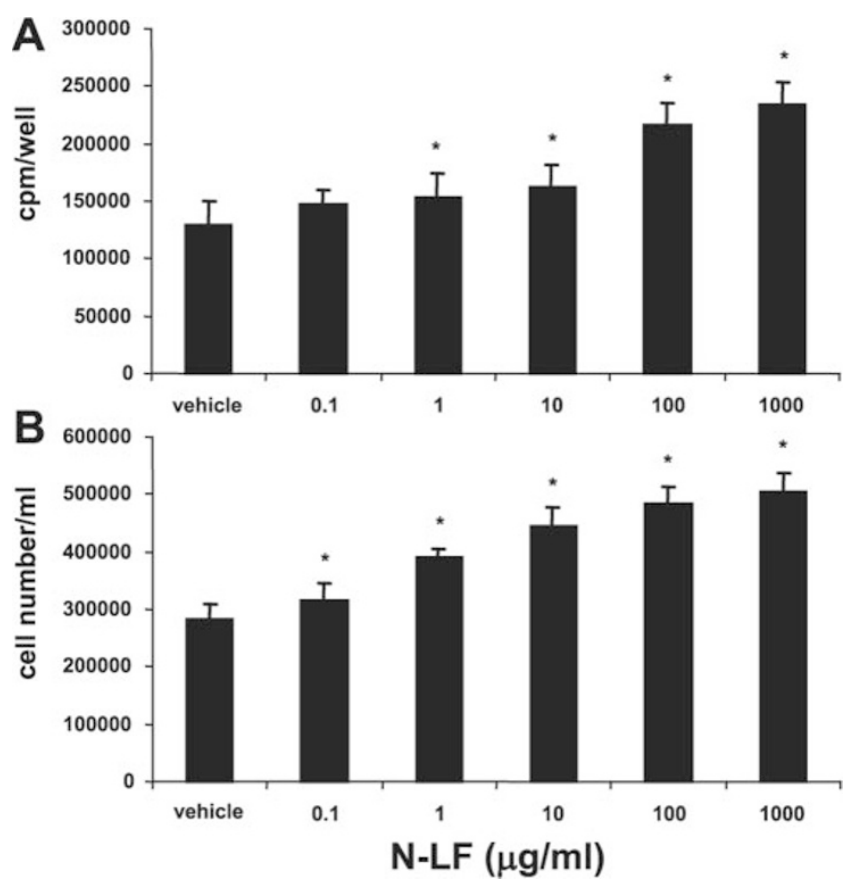

Figure 1. Effects of LF on Caco-2 cell growth. Caco-2 cells were exposed to increasing concentrations of N-LF as described in Methods. Uptake of ${ }^{3} \mathrm{H}$-thymidine $(A)$ and cell count $(B)$ were evaluated. Zero dose corresponds to control cells exposed to vehicle in the same conditions of treated cells. Data are mean $\pm \mathrm{SD}$ of three independent experiments. *Significantly different from $0 \mu \mathrm{g} / \mathrm{mL} \mathrm{N-LF}(p<0.05)$.
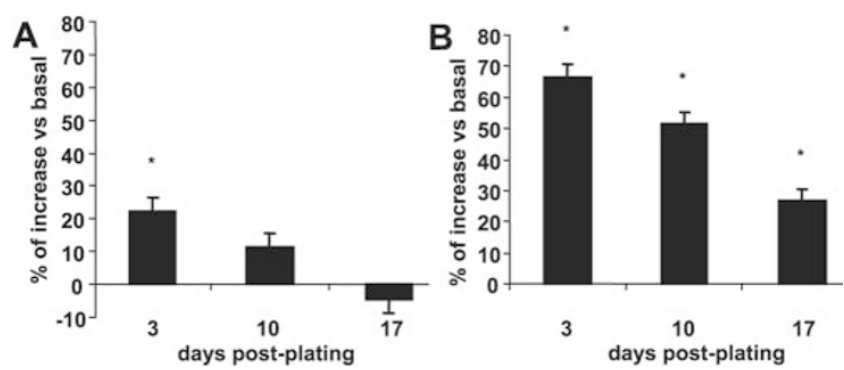

Figure 2. Effects of LF on Caco-2 cell growth at different stages of differentiation. Cell growth was evaluated in Caco-2 cells at 3,10, and $17 \mathrm{~d}$ after plating using uptake of ${ }^{3} \mathrm{H}$-thymidine method. Caco-2 cells were exposed to $1 \mu \mathrm{g} / \mathrm{mL}(A)$ and $100 \mu \mathrm{g} / \mathrm{mL}(B)$ of N-LF. Data were expressed as percentage $v s$ basal condition and are means $\pm \mathrm{SD}$ of three independent experiments. $*$ Significantly different from basal $(p<0.05)$.

Effects of LF on sucrase and lactase activities. Under basal conditions, sucrase and lactase activities progressively increased in growing Caco- 2 cells. Sucrase activity was measurable at $3 \mathrm{~d}$ and peaked between 14 and $16 \mathrm{~d}$ after plating. $\mathrm{N}$-LF induced a dose-dependent increase of sucrase activity, with a peak at $100 \mathrm{ng} / \mathrm{mL}$ (Fig. 3). N-LF also induced an increase in lactase activity, which, however, was independent on its concentration (Fig. 4). Stimulation of lactase and sucrase activities strictly depended on the time of LF addition. Exposure of more immature cells to LF corresponded to the maximal effect. In parallel experiments we added LF to the cells at 3, 6, 10, and $15 \mathrm{~d}$ postplating. The effect was strongest in cells exposed to LF at $3 \mathrm{~d}$ for sucrase activity and in those exposed to LF at $6 \mathrm{~d}$ for lactase activity (Fig. 5). Thus, LF induces a more potent effect on immature cells. 


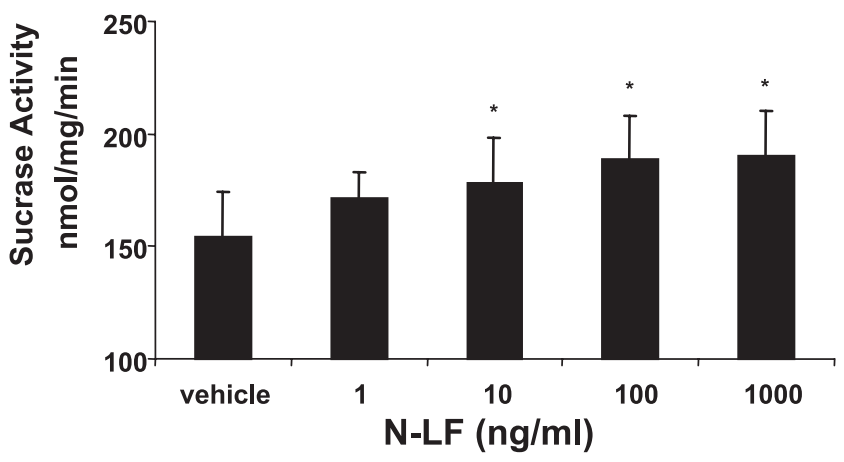

Figure 3. Effects of LF on sucrase activity. Caco-2 cells were stimulated with increasing concentrations of N-LF at $3 \mathrm{~d}$ after plating, and sucrase activity was evaluated as described in "Materials and Methods." Zero dose corresponds to control cells exposed to vehicle in the same conditions of treated cells. Data are expressed as nanomoles of glucose generated per minute and normalized for milligram of protein content. Data are means \pm SD of three independent experiments. *Significantly different from $0 \mathrm{ng} / \mathrm{mL}$ N-LF $(p<0.05)$.

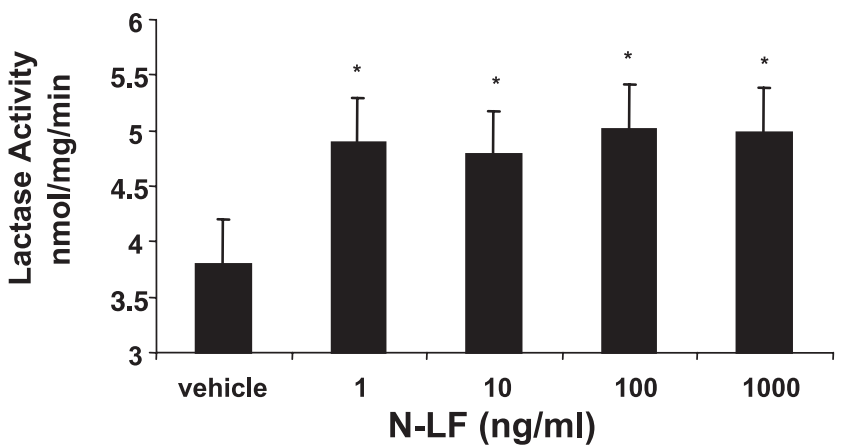

Figure 4. Effects of LF on lactase activity. Caco-2 cells were stimulated with increasing concentrations of N-LF at $6 \mathrm{~d}$ after plating and lactase activity was evaluated as described in Methods. Zero dose corresponds to control cells exposed to vehicle in the same conditions of treated cells. Data are expressed as nanomoles of glucose generated per minute and normalized for milligram of protein content. Data are means $\pm \mathrm{SD}$ of three independent experiments. *Significantly different from $0 \mathrm{ng} / \mathrm{mL} \mathrm{N-LF}(p<0.05)$.
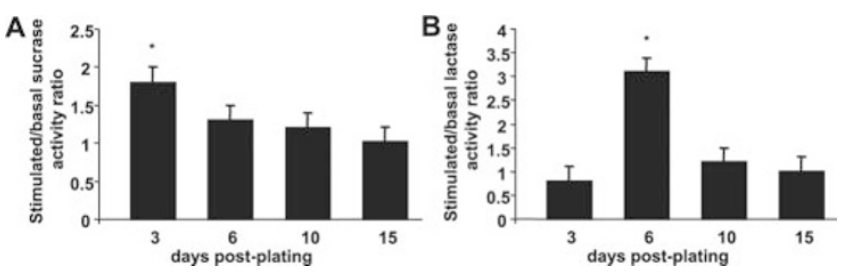

Figure 5. Modulation of disaccharidase activities by LF in Caco-2 cells at different stages of differentiation. Disaccharidase activities were evaluated in Caco-2 cells at 3, 6, 10, and $15 \mathrm{~d}$ after plating. $\mathrm{LF}(100 \mathrm{ng} / \mathrm{mL})$ induced significant stimulation of sucrase $(A)$ and lactase $(B)$ activities 3 and $6 \mathrm{~d}$ after plating respectively. $*$ Significantly different from basal activity $(p<0.05)$.

Biologic effects induced by $L F$ in relation to its ironsaturation status. Because LF exists in iron-saturated and iron-unsaturated isoforms, we investigated changes of cell proliferation, sucrase and lactase activities in Caco-2 cells exposed to N-LF and I-LF. I-LF had a lower effect than N-LF on cell proliferation (Fig. 6). A distinct effect was also detected for differentiation markers. Whereas N-LF induced an increase in sucrase activity in Caco2 cells, I-LF did not (Fig. 7A). In contrast, the two isoforms induced lactase activity to a similar extent (Fig. $7 B$ ). These data suggest that the biologic effects induced by LF depend at least in part, on its iron saturation.

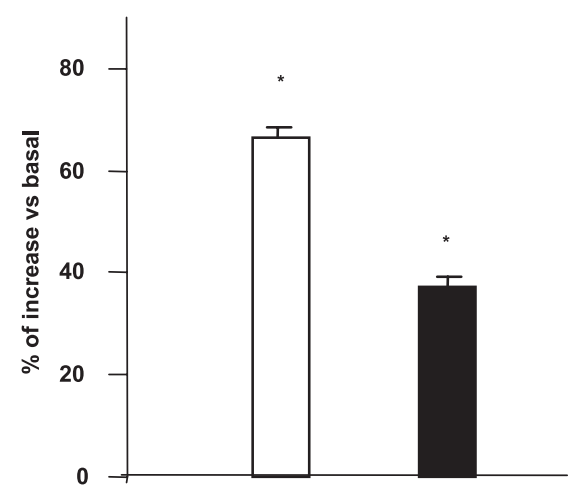

Figure 6. Effect of LF iron-binding status on intestinal growth. Cell proliferation was evaluated in Caco-2 cells after exposure to N-LF (white column) and I-LF (black column). The concentrations used were $100 \mu \mathrm{g} / \mathrm{mL}$. The basal level corresponds to control cells exposed to vehicle in the same conditions of treated cells. Data were expressed as percentage $v s$ basal condition and are means \pm SD of three independent experiments. *Significantly different from basal $(p<0.05)$.
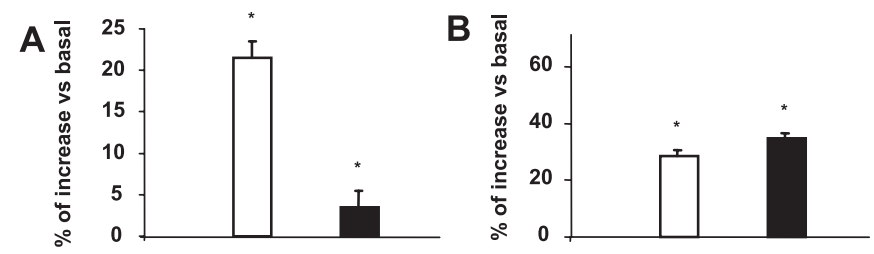

Figure 7. Effect of LF iron-binding status on intestinal differentiation. Differentiation was evaluated in Caco-2 cells after N-LF (white column) and I-LF (black column) exposure. The concentration used was $100 \mathrm{ng} / \mathrm{mL}$ in sucrase $(A)$ and lactase activity $(B)$. The basal level corresponds to control cells exposed to vehicle in the same conditions of treated cells. Data were expressed as percentage $v s$ basal condition and are means \pm SD of three independent experiments. ${ }^{*}$ Significantly different from basal $(p<0.05)$.

Effects of BLF on cell growth and differentiation. We observed ${ }^{3} \mathrm{H}$-thymidine incorporation in Caco-2 cells exposed to bLF (Fig. 8A). bLF was used at high and low concentrations equimolar to human LF. At high doses, bLF showed effects similar to N-LF, but at low doses bLF induced a more potent effect on cell growth. A weak stimulation of sucrase activity, similar to what observed with human LF, was observed with $1 \mathrm{ng} / \mathrm{mL}$ of bLF. At higher bLF concentrations, there was virtually no effect on sucrase activity (Fig. 8B). A reversed pattern of comparative potency by the two LF isoforms was observed for lactase activity. The latter increased more upon bLF than upon human LF stimulation (Fig. 8C).

Lactase and sucrase mRNA expression under LF stimulation. To test the hypothesis that LF effects are exerted at transcriptional level, we determined the specific mRNA levels in baseline conditions and in the presence of maximal effective LF concentration. The experiments were performed in Caco-2 cells in preconfluent condition after $24 \mathrm{~h}$ of bLF stimulation (Fig. 9, $A$ and $B$, respectively). A significant increase of sucrase and lactase mRNA expression was observed with a maximal effect at bLF concentration of $1 \mathrm{ng} / \mathrm{mL}$ dose.

\section{DISCUSSION}

Intestinal length doubles in the last phase of pregnancy and is maximal at birth (26). Intestinal permeability is an indirect measure of intestinal epithelial development and it decreases 

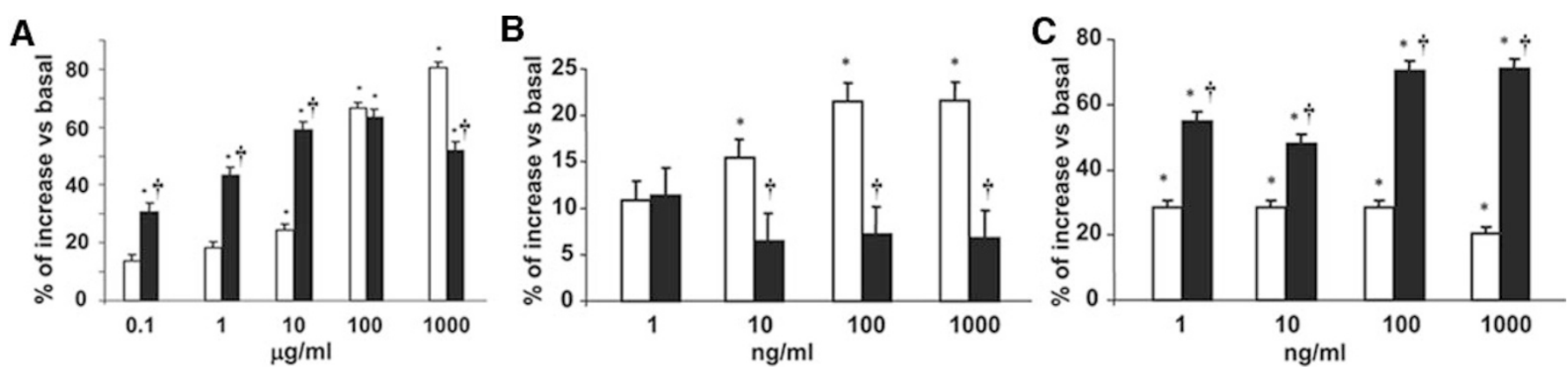

Figure 8. Comparative effects between N-LF and bLF on Caco-2 cell growth and differentiation. Parallel preparations of Caco-2 cells were exposed to increasing concentrations of N-LF (white column) or bLF (black column) as described in "Materials and Methods." Uptake of ${ }^{3} \mathrm{H}$-thymidine $(A)$, sucrase $(B)$, and lactase activities $(C)$ were evaluated. The basal level corresponds to control cells exposed to vehicle in the same conditions of treated cells. Data were expressed as percentage $v s$ basal condition and are means \pm SD of three independent experiments. *Significantly different from basal $(p<0.05)$. †bLF significantly different from N-LF $(p<0.05)$ at the same concentration.
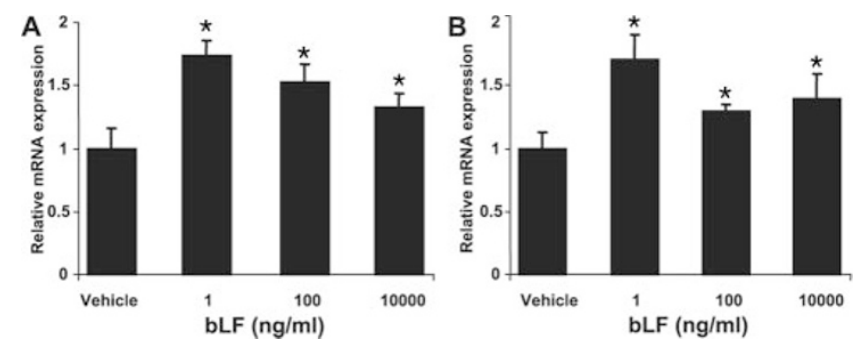

Figure 9. Relative concentration of mRNA for sucrase and lactase in Caco-2 cell line. Relative concentrations of sucrase $(A)$ and lactase mRNA $(B)$ were determined by real-time quantitative PCR. GAPDH was selected as an endogenous RNA control to normalize for differences in the amount of total RNA. Data are expressed as relative mRNA expression and are means \pm SD of two independent experiments. Zero dose corresponds to control cells exposed to vehicle in the same conditions of treated cells. *Significantly different from $0 \mathrm{ng} / \mathrm{ml}$ bLF $(p<0.05)$.

in the first days of life $(27,28)$. Newborn infants fed human milk versus formula had decreased permeability at $28 \mathrm{~d}$ of age (28), indicating a more rapid maturation of intestinal epithelium. This is certainly associated with growth factors in human milk. LF is a major protein component of human milk and exerts numerous physiologic activities, such as enhancement of immune function, defense against pathogenic bacteria and viruses, and stimulation of beneficial gut microflora. Its also promotes gut development and its functions (29). We observed a close relationship between LF concentration and its biologic effects on Caco-2 growth and differentiation. High LF concentrations induced a potent and rapid increase in intestinal epithelial cell proliferation, whereas low LF concentrations induced stimulation of intestinal differentiation. These findings suggest that LF is a key modulator of intestinal epithelium development. They also support the unique properties of colostrum, suggesting that, in addition to its antiinfectious and nutritional effects, it is also involved in the rapid intestinal cell proliferation that is observed immediately after birth. The data on lactase and sucrase activities support the role of LF in the early intestinal development and show that LF directly promotes enterocyte differentiation. Sucrase and lactase show a sugar-dependent rapid increase in the first days of life (6). Interestingly, a rapid increase is observed in disaccharidase activities in jejunal fluid during the first, second, and third weeks of life (30) in parallel with the decrease in LF in human milk (15). We speculate that the higher concentrations of LF in colostrum contributes to the early proliferation of intestinal cells, which then differentiate as a result of its decreased concentration. Oguchi et al. (18) investigated the effects of LF on brush border enzymes and found that the iron-saturated form of LF induces sucrase activity but has no effect on alkaline phosphatase activity. However, their experiments were performed in confluent Caco- 2 cells undergoing differentiation. Here we show that LF stimulates both lactase and sucrase activity on subconfluent cells, i.e. when added at an early phase of differentiation. These findings suggest a positive role of LF in human milk in regulating the levels of lactase activity. The increase of lactase activity during the early weeks of life in preterm infants is greater than the increase in small intestinal mucosal mass (31). Therefore, other factors play a crucial role in stimulating lactase development. Lactase is expressed at higher levels in breast-fed than in formula-fed infants (7). Lactase-specific activity may be regulated via transcriptional or post-translational events, as well as by controlling the break-down of lactase protein. Human milk is a rich source of lactose as well as of growth factors and of components of the immune system. Any of these moieties may regulate lactase expression either alone or in combination with lactoferrin. Goda et al. (32) suggested a regulatory mechanism of sucrase and lactase gene transcription and protein translation in differentiation process of epithelial intestinal cells. Our data support the concept that LF acts directly on the enterocyte at transcriptional level. It does this in a concentration range typical of mature milk. Therefore, LF is able to modulate as a transcriptional factor mRNA expression in immature intestinal cells typical of intestinal crypt regions. Of course, this last observation should be confirmed in primary cultures obtained from human specimens.

Oguchi et al. (18) reported that the iron-saturated LF isoform stimulated the proliferation of confluent (mature) Caco-2 cells, whereas the iron-unsaturated form suppresses it. In contrast, Nichols reported that iron is not required for LFinduced growth of enterocyte (33). Iron saturation of N-LF is $10 \%$ in human milk and does not change during lactation (34). Our data indicate that the effects by LF on Caco-2 partially depend on iron saturation. In conclusion, the results of this 
research show that LF induces intestinal cell growth and differentiation and it does this in a concentration-dependent fashion, providing an explanation for the age-dependent concentration pattern of LF in human milk. At high concentrations, LF acts as an optimal intestinal growth factor, whereas at low concentrations, it induces intestinal differentiation and a strong inhibition of cell growth. In addition, LF biologic effects are observed in immature Caco-2 only. As a result, there is probably an excess of crypt-type enterocytes that have an ion secretory rather than an absorptive pattern in the very early phase after birth (35). This probably promotes the fluidification and elimination of meconium. Interestingly, the developmental pattern of LF corresponds to that described for guanylate cyclase activity (36), a regulator of enterocyte ion transport channels, and also of cell proliferation, which also peaks in the first $3 \mathrm{~d}$ of life (37). Recent data on the guanylate cyclase endogenous ligand, guanylin, suggest that fluidification of intestinal content is regulated developmentally to promote meconium output (38). By promoting rapid proliferation of immature enterocytes that are in a secretive ion transport state, LF could be a key component of this complex interplay.

Finally, our data also have practical implications. They indicate that bovine LF exerts effects on human intestinal cells that are similar to those induced by the human isoform. The comparative experiments showed that bovine isoform is even more potent than human LF in inducing cell growth and lactase expression. LF has been proposed for a number of therapeutic purposes in human disorders, including intestinal inflammation, cancer prevention, and rotavirus infection (3941). Our findings add to this concept and suggest that bovine LF could be used as a functional component of infant formula to promote intestinal epithelial growth and differentiation. This effect is highly desirable, particularly in premature newborn infants or in intestinal diseases associated with epithelial atrophy.

Acknowledgments. The authors thank Jean Ann Gilder for editing the text.

\section{REFERENCES}

1. Shanklin DR, Cooke RJ 1993 Effects of intrauterine growth on intestinal length in the human fetus. Biol Neonate 64:76-81

2. Fitzsimmons J, Chinn A, Shepard TH 1988 Normal length of the human fetal gastrointestinal tract. Pediatr Pathol 8:633-641

3. Ichiba H, Kusuda S, Itagane Y, Fujita K, Issiki G 1992 Measurement of growth promoting activity in human milk using a fetal small intestinal cell line. Biol Neonate 61:47-53

4. Qin YD, Luo X, Huang DL, Xu CZ 2004 Dynamic changes of enzymes activities and growth factors contents in human colostrums. Zhonghua Fu Chan Ke Za Zhi 39:449-452

5. Hirai C, Ichiba H, Shintaku H, Yamano T, Kusuda S 2002 Trophic effect of multiple growth factors in amniotic fluid or human milk on cultured human fetal small intestinal cells. J Pediatr Gastroenterol Nutr 34:524-528

6. Smith MW 1992 Diet effects on enterocyte development. Proc Nutr Soc 51:173-178

7. Shulman RJ, Schanler RJ, Lau C, Heitkemper M, Ou CN, Smith EO 1998 Early feeding, feeding tolerance, and lactase activity in preterm infants. J Pediatr 133:645649

8. Olsen WA, Lloyd M, Korsmo H, He YZ 1996 Regulation of sucrase and lactase in Caco-2 cells: relationship to nuclear factors SIF-1 and NF-LPH-1. Am J Physiol 271:G707-G713

9. Hauri HP, Sterch EE, Bienz D, Franzen JA, Marxer A 1985 Expression and intracellular transport of microvillus membrane hydrolases in human intestinal epithelial cells. J Cell Biol 101:838-851

10. Rings EH, de Boer PA, Moorman AF, van Beers EH, Dekker J, Montgomery RK, Grand RJ, Buller HA 1992 Lactase gene expression during early development of rat small intestine. Gastroenterology 103:1154-1161
11. Yamada Y, Saito S, Morikawa H 1998 Hepatocyte growth factor in human breast milk. Am J Reprod Immunol 40:112-120

12. Farnaud S, Evans RW 2003 Lactoferrin-a multifunctional protein with antimicrobial properties. Mol Immunol 40:395-405

13. Niemela A, Kulomaa M, Vija P, Tuohimaa P, Saarikoski S 1989 Lactoferrin in human amniotic fluid. Hum Reprod 4:99-101

14. Masson PL, Heremans JF 1971 Lactoferrin in milk from different species. Comp Biochem Physiol B 39:119-129

15. Hirai Y, Kawakata N, Satoh K, Ikeda Y, Hisayasu S, Orimo H, Yoshino Y 1990 Concentrations of lactoferrin and iron in human milk at different stages of lactation. J Nutr Sci Vitaminol (Tokyo) 36:531-544

16. Davidson LA, Lonnerdal B 1987 Persistence of human milk proteins in the breastfed infant. Acta Paediatr Scand 76:733-740

17. Kawakami H, Lonnerdal B 1991 Isolation and function of a receptor for human lactoferrin in human fetal intestinal brush-border membranes. Am J Physiol 261:G841-G846

18. Oguchi S, Walker WA, Sanderson IR 1995 Iron saturation alters the effect of lactoferrin on the proliferation and differentiation of human enterocytes (Caco-2 cells). Biol Neonate 67:330-339

19. Fan MZ, Stoll B, Jiang R, Burrin DG 2001 Enterocyte digestive enzyme activity along the crypt-villus and longitudinal axes in the neonatal pig small intestine. $\mathrm{J}$ Anim Sci 79:371-381

20. Norrby K 2004 Human apo-lactoferrin enhances angiogenesis mediated by vascular endothelial growth factor A in vivo. J Vasc Res 41:293-304

21. Grasset E, Pinto M, Dussaulx E, Zweibaum E, Desjeux JF 1984 Epithelial properties of human colonic carcinoma cell line Caco-2: electrical parameters. Am J Physiol 247:C260-C268

22. Fogh J, Fogh JM, Orfeo T 1977 One hundred and twenty seven cultured human tumor cell lines producing tumors in nude mice. J Natl Cancer Inst 59:221-226

23. Pinto M, Robine-Leon S, Appay MD, Kedinger M, Triadou N, Dussaulx E, Lacroix B, Simon-Assmann P, Haffen K, Fogh J, Zweibaum E 1983 Enterocyte-like differentiation and polarization of the human colon carcinoma cell line caco-2 in culture. Biol Cell 47:323-330

24. Spik G, Coddeville B, Montreuil J 1988 Comparative study of the primary structures of sero-, lacto- and ovotransferrin glycans from different species. Biochimie 70:1459-1469

25. Messer M, Dahlqvist A 1966 A one-step ultramicro method for the assay of intestinal disaccharidases. Anal Biochem 14:376-392

26. Touloukian RJ, Smith GJ 1983 Normal intestinal length in preterm infants. J Pediatr Surg 18:720-723

27. van Elburg RM, Fetter WP, Bunkers CM, Heymans HS 2003 Intestinal permeability in relation to birth weight and gestational and postnatal age. Arch Dis Child Fetal Neonatal Ed 88:F52-F55

28. Shulman RJ, Schanler RJ, Lau C, Heitkemper M, Ou CN, Smith EO 1998 Early feeding, antenatal glucocorticoids, and human milk decrease intestinal permeability in preterm infants. Pediatr Res 44:519-523

29. Lonnerdal B 2003 Nutritional and physiologic significance of human milk proteins. Am J Clin Nutr 77:1537S-1543S

30. Mayne AJ, Brown GA, Sule D, McNeish AS 1986 Postnatal development of disaccharidase activities in jejunal fluid of preterm neonates. Gut 27:1357-1361

31. Shulman RJ, Wong WW, Smith EO 2005 Influence of changes in lactase activity and small intestinal mucosal growth on lactose digestion and absorption in preterm infants. Am J Clin Nutr 81:472-479

32. Goda T, Yasutake H, Tanaka T, Takase S 1999 Lactase-phlorizin hydrolase and sucrase-isomaltase genes are expressed differently along the villus-crypt axis of rat jejunum. J Nutr 129:1107-1113

33. Nichols BL, McKee KS, Huebers HA 1990 Iron is not required in the lactoferrin stimulation of thymidine incorporation into the DNA of rat crypt enterocytes. Pediatr Res 27:525-528

34. Montagne P, Cuilliere ML, Mole C, Bene MC, Faure G 2001 Changes in lactoferrin and lysozyme levels in human milk during the first twelve weeks of lactation. Adv Exp Med Biol 501:241-247

35. Babyatsky MW, Podolsky DK 2003 Growth and development of the gastrointestinal tract. In: Yamada T, Alpers DH, Laine L, Kaplowits N, Chung O, Powell DW (eds) Textbook of Gastroenterology, Lippincott Williams \& Wilkins, Philadelphia, pp $521-556$

36. Guarino A, Cohen MB, Giannella RA 1987 Small and large intestinal guanylate cyclase activity in children: effect of age and stimulation by Escherichia coli heat-stable enterotoxin. Pediatr Res 21:551-555

37. Giannella RA, Mann EA 2003 E. coli heat-stable enterotoxin and guanylyl cyclase C: new functions and unsuspected actions. Trans Am Clin Climatol Assoc 114:67-85

38. Albano F, De Marco G, Berni Canani R, Cirillo P, Buccigrossi V, Giannella RA, Guarino A 2005 Guanylin and E. coli heat-stable enterotoxin induce chloride secretion through direct interaction with basolateral compartment of rat and human colonic cells. Pediatr Res 58:159-163

39. Togawa J, Nagase H, Tanaka K, Inamori M, Nakajima A, Ueno N, Saito T, Sekihara H 2002 Oral administration of lactoferrin reduces colitis in rats via modulation of the immune system and correction of cytokine imbalance. J Gastroenterol Hepatol $17: 1291-1298$

40. Tsuda H, Sekine K, Fujita K, Ligo M 2002 Cancer prevention by bovine lactoferrin and underlying mechanisms - a review of experimental and clinical studies. Biochem Cell Biol 80:131-136

41. Superti F, Ammendolia MG, Valenti P, Seganti L 1997 Antirotaviral activity of milk proteins: lactoferrin prevents rotavirus infection in the enterocyte-like cell line HT-29. Med Microbiol Immunol (Berl) 186:83-91 